\title{
IMPLEMENTASI SISTEM INFORMASI MANAJEMEN BERBASIS TEKNOLOGI INFORMASI DI UNIVERSITAS NEGERI MAKASSAR
}

\author{
Muhammad Nasrullah \\ Program Studi Pendidikan IPS Program Pascasarjana UNM \\ Email: nasrullahmujetaba@yahoo.com
}

\begin{abstract}
ABSTRAK
Adapun Tujuan penelitian ini adalah untuk mengetahui implementasi sistem informasi manajemen berbasis teknologi informasi di Universitas Negeri Makassar, dilihat dari aspek komunikasi, sumber daya, dan sikap pelaksana. Penelitian ini menggunakan pendekatan deskriptif kualitatif dengan teknik pengumpulan data melalui wawancara mendalam (indepth interview), observasi dan studi dokumentawi.

Hasil penelitian menunjukkan bahwa implementasi sistem informasi manajemen berbasis teknologi informasi di UNM dilihat dari aspek komunikasi belum berjalan efektif. Hal ini dapat dilihat dari kurangnya tingkat pemahaman informasi dari pimpinan atas sampai kepada pelaksana yang memuat kejelasan isi, tujuan, arah, kelompok sasaran, dan pembagian tugas yang spesifik dari implementasi sistem informasi manajemen berbasis teknologi informasi. Dilihat dari aspek sumber daya (manusia dan finansial) kurang berjalan efektif. Hal ini dapat dilihat dari kuantitas sumber daya manusia pengelola profesional masih kurang, kualitas sumber daya manusia pengelola kurang inovatif dan kreatif dalam mengembangkan sistem aplikasi, dan dukungan dana yang ada terbatas hanya pada standar minimal layanan. Dilihat dari aspek sikap pelaksana menunjukkan resistensi dalam hal kurang optimalnya kinerja layanan dan jaringan sebagai akibat ketidakterjangkauan akses ke seluruh unit-unit yang ada dalam lingkungan UNM.
\end{abstract}

Kata Kata: Implementasi kebijakan, SIM berbasis Teknologi Informasi

\section{PENDAHULUAN}

Pada dasarnya, sistem informasi manajemen merupakan suatu komponen yang terdiri dari manusia, teknologi informasi dan prosedur kerja yang memproses, menyimpan, menganalisis dan menyebarkan informasi untuk mencapai suatu tujuan. Sistem informasi manajemen berbasis teknologi informasi adalah suatu sistem penghasil informasi yang mendukung sekelompok manajer dengan memanfaatkan teknologi informasi (McLeod, Jr. 2001:49). Penggunaan teknologi informasi ini pada akhirnya akan berpengaruh terhadap kinerja organisasi. Saat ini tidak hanya pada organisasi/perusahaan swasta akan tetapi juga pada instansi pemerintah. Teknologi informasi yang berbasis teknologi informasi ini akan berdampak pada aktivitas pegawai, memudahkan pegawai untuk tidak lagi melakukan tugas secara manual sehingga pekerjaan dapat terselesaikan secara efektif dan efisien.

Demikian halnya di Universitas Negeri Makassar (UNM) sebagai institusi pendidikan yang berbasis teknologi informasi. Dalam pengelolaan dan pengembangannya, UNM menggunakan 
sistem informasi manajemen baik itu untuk kegiatan akademik maupun kegiatan nonakademik sebagai bentuk support dengan tujuan agar mahasiswa dan pegawai dapat menyelesaikan aktivitasnya secara efektif dan efisien yang dikenal dengan istilah simpadu (sistem informasi dan manajemen terpadu).

Berdasarkan penelusuran data dokumentasi ICT Center UNM, diperoleh keterangan bahwa UNM sudah menggunakan sistem informasi manajemen sejak tahun 1991 (Sisdiksat) yang kemudian disempurnakan menjadi ICT sejak tahun 2008 hingga saat ini. Saat ini pengelolaan dan pengembangan sistem informasi manajemen berbasis teknologi informasi berada di unit ICT Center UNM. Sistem informasi ini dapat digunakan dengan membuka web browser seperti Mozzila Firefox, Google Chrome, Opera dan web browser lainnya, dengan laman www.unm.ac.id. Laman tersebut menyediakan sistem seperti: Simpadu, Webmail, E-learning, Blog, LPSE, Ojs, Digilib, dan berita lainnya.

Sistem informasi manajemen berbasis teknologi informasi dengan sistem online ini, dapat digunakan dan dapat dimanfaatkan oleh seluruh civitas akademika Universitas Negeri Makassar. Bagi mahasiswa, sistem ini dapat digunakan untuk melihat biodata, melihat nilai, KRS online, Evaluasi Dosen oleh Mahasiswa (EDOM), jadwal kuliah dan informasi akademik lainnya. Bagi dosen, sistem ini dapat digunakan untuk melihat biodata, aktivitas mengajar, dosen wali, KRS, menginput data nilai, bahan kuliah, tugas kuliah serta data akademik lainnya, termasuk juga untuk pembelajaran $e$ learning.

Pemanfaatan teknologi informasi pada bidang layanan administrasi akademik maupun non akademik di UNM ini sudah menjadi suatu kebutuhan, bukan hanya sekedar prestise atau lifestyle manajemen pendidikan tinggi modern. Dalam implementasinya, banyak kendala yang ditemui dalam menerapkan teknologi informasi dalam proses pengelolaan kelembagaan ini baik faktor teknis maupun non teknis. Hal ini sejalan dengan pendapat Van Meter dan Van Horn (Subarsono, 2005:99) yang mengemukkan bahwa "ada enam variabel yang mempengaruhi kinerja implementasi, yakni (1) Standar dan sasaran kebijakan, (2) sumberdaya, (3) komunikasi antar organisasi dan penguatan aktivitas, (4) karakteristik agen pelaksana, (5) lingkungan ekonomi, sosial, dan politik, (6) sikap para pelaksana".

Dari aspek komunikasi, para pimpinan universitas perlu menyampaikan dengan jelas kepada pegawai pelaksana agar mereka dapat mengetahui, memahami apa yang menjadi isi, tujuan, arah, dan kelompok sasaran dari implementasi sistem informasi manajemen tersebut, agar para pegawai pelaksana dapat mempersiapkan dengan benar apa yang harus dipersiapkan dan lakukan untuk melaksanakan kebijakan tersebut agar apa yang menjadi tujuan dan sasaran kebijakan dapat dicapai sesuai dengan yang diharapkan. Dari aspek sumber daya (manusia), ketertinggalan-ketertinggalan seorang pegawai yang tidak memiliki pengetahuan atau kemampuan yang dibutuhkan untuk melaksanakan pekerjaan yang penuh tantangan harus mendapat perhatian lebih dari pimpinan. Disamping itu, faktor sumber daya finansial (anggaran) cukup mempengaruhi pelaksanaan implementasi sistem informasi manajemen ini, utama menyangkut pengadaan sarana dan prasarana yang akan mendukung kinerja jaringan. Dari aspek sikap pelaksana (pegawai), terbatasnya ruang lingkup sosialisasi dan informasi mengenai implementasi sistem informasi manajemen tentu akan membuat penggunaan sistem informasi manajemen oleh pegawai menjadi tidak optimal yang kemudian akan menjadi penghambat keberadaan pekerjaan.

Hal ini perlu mendapat perhatian yang lebih serius mengingat perannya yang 
cukup sentral dalam proses pemberian layanan akademik yang prima kepada seluruh stakeholders, dan juga dalam proses pengambilan keputusan manajerial ataupun keputusan-keputusan lainnya. Untuk meningkatkan efektivitas implementasi ini, yang jelas akan berpengaruh pada efektivitas pencapaian penyelenggaraan pendidikan yang dilaksanakan oleh universitas, maka segala hal yang mempengaruhi efektivitas implementasi sistem informasi manajemen berbasis teknologi informasi di UNM, seperti komunikasi, sumber daya, dan sikap pelaksana perlu segera dibenahi.

\section{KAJIAN TEORI}

\section{Pengertian Implementasi Kebijakan}

Implementasi kebijakan publik merupakan salah satu tahapan dari proses kebijakan publik sekaligus studi yang sangat krusial. Bersifat krusial karena bagaimanapun baiknya suatu kebijakan, kalau tidak dipersiapkan dan direncanakan secara baik dalam implementasinya, maka tujuan kebijakan tidak akan pernah bisa diwujudkan. Donald S. Van Mater dan Carl E. Va (Widodo, 2009:86) mengemukakan bahwa:

Implementasi kebijakan publik merupakan suatu tindakan, baik yang dilakukan oleh pihak pemerintah maupun individu atau kelompok yang diarahkan untuk mencapai tujuan-tujuan yang telah ditetapkan dalam suatu keputusan kebijakan sebelumnya. Pada suatu tindakan-tindakan ini, berusaha mentransformasikan keputusan-keputusan menjadi pola-pola operasional serta melanjutkan usaha-usaha tersebut untuk mencapai perubahan, baik besar maupun kecil yang diamanatkan oleh keputusankeputusan kebijakan tertentu.

Mazmanian dan Sebatier (Widodo, 2009:87) menyatakan bahwa:

Hakikat utama implementasi kebijakan adalah memahami apa yang seharusnya terjadi sesudah suatu program dinyatakan berlaku atau dirumuskan. Pemahaman tadi mencakup usaha-usaha yang mengadministrasikannya dan untuk menimbulkan dampak nyata pada masyarakat atau kejadian-kejadian.

Pendapat lain Dunn (2003:80) menyatakan bahwa "Implementasi kebijakan adalah pelaksanaan dan pengendalian arah tindakan kebijakan sampai dicapainya hasil kebijakan". Sesungguhnya bukanlah implementasi kebijakan sekedar bersangkut paut dengan mekanisme penjabaran keputusankeputusan politik ke dalam prosedurprosedur rutin lewat saluran-saluran birokrasi, melainkan lebih dari itu, ia mengangkat masalah konflik, keputusan dan siapa yang memperoleh apa dari suatu kebijakan. Oleh sebab itu tidak terlalu salah jika dikatakan implementasi kebijakan merupakan aspek yang sangat penting dari seluruh proses kebijakan. Van Mater dan Van Horn (Wahab, 2004:65) menyatakan bahwa:

Implementasi kebijaksanaan negara merupakan tindakan-tindakan yang dilakukan baik oleh individuindividu atau kelompok-kelompok pemerintah atau swasta yang diarahkan tercapainya tujuan-tujuan yang telah digariskan dalam keputusan kebijakan.

Dari berbagai pendapat ahli tersebut di atas, maka dapat disimpulkan bahwa Implementasi kebijakan adalah suatu proses melaksanakan sesuatu sehingga menimbulkan dampak atau akibat terhadap sesuatu.

\section{Model Implementasi Kebijakan}

Keberhasilan implementasi kebijakan ditentukan oleh banyak faktor, dan masing-masing faktor tersebut saling berhubungan satu sama lain. Untuk memperkaya pemahaman tentang berbagai faktor yang terkait di dalam implementasi, maka pada bagian ini dielaborasi beberapa model implementasi kebijakan dan dijadikan sebagai landasan pijak dalam penelitian ini. 


\section{a. Model George C. Edwads III}

Pandangan Edwads III (Widodo, 2009:107) bahwa "Implementasi kebijakan dipengaruhi oleh empat variabel, yakni: (1) komunikasi; (2) sumberdaya; (3) disposisi, dan (4) struktur birokrasi."

1) Komunikasi

Komunikasi diartikan sebagai proses penyampaian informasi komunikator kepada komunikan. Komunikasi kebijakan berarti proses penyampaian informasi kebijakan dari pembuat kebijakan kepada pelaksana kebijakan maupun kepada sasaran kebijakan. Informasi kebiijakan publik perlu disampaikan kepada pelaku kebijakan agar para pelaku dapat mengetahui, memahami apa yang menjadi isi, tujuan, arah, kelompok sasaran kebijakan agar para pelaku kebijakan dapat mempersiapkan dengan benar apa yang harus dipersiapkan dan lakukan untuk melaksanakan kebijakan publik agar apa yang menjadi tujuan dan sasaran kebijakan dapat dicapai sesuai dengan yang diharapkan.

2) Sumber daya

Menurut Edward III, sumber daya dibagi menjadi beberapa bagaian, diantaranya: meliputi sumber daya manusia, sumber daya anggaran, sumber daya sarana dan prasarana, sumber daya informasi, dan juga sumber daya kewenagan.

3) Disposisi

Arti dari disposisi itu sendiri merupakan kemauan, keinginan, dan kecenderungan para pelaku kebijakan untuk melaksanakan kebijakan secara bersungguh-sungguh sehingga apa yang menjadi tujuan kebijakan dapat diwujudkan. Disposisi ini akan muncul diantara para pelaku kebijakan, manakala akan menguntungkan tidak hanya organisasinya, tetapi juga dirinya. Mereka akan tahu bahwa kebijakan akan menguntungkan organisasi dan dirinya, manakala mereka cukup pengetahuan dan mereka sangat mendalami dan memhaminya.

4) Struktur birokrasi

Struktur birokrasi ini mencakup aspekaspek seperti struktur organisasi, pembagian kewenangan, hubungan antara unit-unit organisasi yang ada dalam organisasi yang bersangkutan, dan hubungan organisasi dengan organisasi luar dan sebagainya. Oleh karena itu, struktur birokrasi mencakup dimensi fragmentasi dan standar prosedur operasi (SOP) yang akan memudahkan dan menyeragamkan tindakan dari para pelaksana kebijakan dalam melaksanakan apa yang menjadi bidang tugasnya.

\section{b. Model Donald Van Meter dan Carel Van Horn}

Van Meter dan Van Horn (dalam Wibawa et al., 1994:19), "Merumuskan sebuah abstraksi yang menunjukkan hubungan antar berbagai variabel yang mempengaruhi kinerja suatu kebijakan." Selanjutnya Van Meter dan Van Horn (Subarsono, 2005:99) mengemukkan ada enam variabel yang mempengaruhi kinerja implementasi, yakni "(a) Standar dan sasaran kebijakan, (b) sumberdaya, (c) komunikasi antar organisasi dan penguatan aktivitas, (d) karakteristik agen pelaksana, (e) lingkungan ekonomi, sosial, dan politik, (f) sikap para pelaksana".

1) Standar dan tujuan kebijakan

Standar dan tujuan kebijakan diperlukan untuk mengarahkan dalam melaksanakan kebijakan, hal tersebut dilakukan agar sesuai dengan program yang sudah direncanakan.

2) Sumberdaya

Sumber daya kebijakan merupakan keberhasilan proses implementasi kebijakan yang dipengaruhi dengan pemanfaatan sumber daya manusia, biaya, dan waktu. Sumber-sumber kebijakan tersebut sangat diperlukan untuk keberhasilan suatu kebijakan yang dibuat oleh pemerintah. Sumber daya manusia sangat penting karena 
sebagai sumber penggerak dan pelaksana kebijakan, modal diperlukan untuk kelancaran pembiayaan kebijakan agar tidak menghambat proses kebijakan. Waktu merupakan bagian yang penting dalam pelaksanaan kebijakan, karena waktu sebagai pendukung keberhasilan kebijakan. Sumber daya waktu merupakan penentu pemerintah dalam merencanakan dan melaksanakan kebijakan.

3) Komunikasi antar organisasi dan penguatan aktivitas

Komunikasi antar organisasi dan penguatan aktivitas memegang peranan penting bagi berlangsungnya koordinasi implementasi kebijakan. Standar dan tujuan kebijakan memiliki efek tidak langsung pada kinerja, apa pengaruh ini terhadap variabel dependen ditengahi oleh variabel independen lain. Jelas yang memberikan pelayanan publik akan dipengaruhi oleh cara yang standar dan tujuan komunikasi untuk pelaksana dan sejauh mana standars dan tujuan memfasilitasi pengawasan dan penegakan hukum. Standar dan tujuan tidak langsung berdampak pada disposisi pelaksana melalui kegiatan komunikasi interorganisasi.

4) Karakteristik agen pelaksana

Hal ini sangat penting karena kinerja implementasi kebijakan publik akan sangat banyak dipengaruhi oleh ciri-ciri yang tepat serta cocok dengan para badan atau instansi pelaksananya. Subarsono mengungkapkan kualitas dari suatu kebijakan dipengaruhi oleh kualitas atau ciri-ciri dari para aktor, kualitas tersebut adalah tingkat pendidikan, kompetensi dalam bidangnya, pengalaman kerja, dan integritas moralnya (Subarsono, 2006:7).

5) Lingkungan ekonomi, sosial dan politik Lingkungan ekonomi, sosial dan politik pada kebijakan publik merupakan pusat perhatian yang besar selama dasawarsa yang lalu. Van Meter dan Vanhorn mengungkapkan:"Sejauh mana lingkungan eksternal ikut mendukung keberhasilan kebijakan publik yang telah ditetapkan, lingkungan eksternal tersebut adalah ekonomi, sosial, dan politik......dukungan sumber daya ekonomi dapat mendukung keberhasilan implementasi kebijakan dan dalam lingkungan politik dukungan elite politik sangat diperlukan dalam mendukung keberhasilan implementasi kebijakan".

6) Sikap para pelaksana

Sikap para pelaksana adalah mencakup struktur birokrasi, norma-norma, dan pola-pola hubungan yang terjadi dalam birokrasi. Sikap para pelaksana dalam menjalankan tugas dan tanggungjawab sebagai pelaksana kebijakan harus dilandasi dengan sikap disiplin. Hal tersebut dilakukan karena dapat mempengaruhi keberhasilan implementasi kebijakan, setiap badan/instansi pelaksana kebijakan harus merasa memiliki terhadap tugasnya masing-masing berdasarkan rencana yang telah ditetapkan sebelumnya.

\section{c. Model Daniel A. Mazmanian dan Paul A. Sabateir}

Teori Daniel A. Mazmanian dan Paul A. Sabateir yang dikenal dengan model kerangka analisis implementasi. Dalam esainya, Mazmanian dan Sabateir mencoba memperkirakan kondisi apa yang mendorong atau menghambat suatu implementasi kebijakan. Keduanya berpendapat bahwa implementasi yang ideal memerlukan seperangkat kondisi optimal. Di dalam pemetaan model ini bersifat sentralistis (dari atas ke bawah) dan lebih berada di mekanisme paksa dari pada mekanisme pasar. Implementasi kebijakan berdasarkan model pendekatan sentralisitis akan menjadi efektif apabila memenuhi enam syarat: (a) tujuan yang jelas dan konsisten, (b) teori kausal yang memadai tentang bagaimana cara melahirkan perubahan, (c) struktur implementasi yang disusun secara legal, 
(d) para pelaksana implementasi yang memiliki keahlian dan komitmen, dukungan dari kelompok kepentingan dan penguasa, (f) perubahan dalam kondisi sosio-ekonomi yang tidak melemahkan dukungan kelompok dan penguasa (Parsons, 2006). Selanjutnya Mazmanian dan Paul A. Sabateir (Dwidjowijoto (2006:129) menjelaskan "Ada tiga kelompok variabel yang mempengaruhi keberhasilan implementasi, yaitu: (a) karakteristik dari masalah, (b) karakteristik kebijakan, (c) lingkungan."

Untuk kepentingan penelitian ini, maka dalam menganalisis implementasi sistem informasi manajemen berbasis teknologi informasi di Universitas Negeri Makassar, peneliti akan mengacu pada model implementasi kebijakan Van Meter dan Van Horn, namun, hanya akan menggunakan 3 variabel yang dianggap sangat relevan dengan kondisi implementasi sistem informasi manajemen berbasis teknologi informasi di Universitas Negeri Makassar, yaitu variabel komunikasi, sumber daya, dan sikap pelaksana. Ketiga variabel ini diasumsukan sebagai faktor-faktor terpenting yang perlu dianalisis secara mendalam untuk mewujudkan keefektifan dalam implementasi suatu kebijakan.

\section{METODE PENELITIAN}

Jenis penelitian yang digunakan yaitu penelitian kualitatif dengan tujuan untuk mendeskripsikan implementasi sistem informasi manajemen berbasis teknologi informasi di Universitas Negeri Makassar. Fokus yang diselidiki adalah implementasi sistem informasi manajemen berbasis teknologi informasi, dengan dimensi: (1) komunikasi, (2) sumber daya, dan (3) sikap pelaksana.

Data-data hasil penelitian diperoleh dari berbagai sumber guna menjawab permasalahan penelitian, yaitu: 1) data primer, 2) data primer, sepertiL pembantu rektor II, kepala Biro Akademik
Perencanaan dan sistem informasi (BAPSI) UNM, pembantu dekan bidang akademikm ketua program studi, kepala baigan, pegawai, dosen dan mahasiswa. Sedangkan sumber data sekundernya diperoleh melalui dokumen-dokumen perencanaan dan program, dokumen pemeliharaan dan keberlanjutan program.

Untuk memperoleh data yang obyektif pada penelitian ini dipergunakan teknik pengumpulan data, yaitu: 1) wawancara, 2) observasi, dan 3) dokumentasi. Sedangkan Pemerikaan keabsahan data dilakukan untuk menguji kredibilitas data atau kepercayaan terhadap data hasil penelitian. Adapun cara-cara yang dilakukan dalam pemeriksaan keabsahan data adalah; 1) Perpanjangan pengamatan, 2) Meningkatkan ketekunan, 3) Triangulasi, dan 4) Member Check.

Teknik analisis data yang digunakan dalam penelitian ini adalah dengan analisis yang dilakukan secara terus-menerus baik dalam proses pengumpulan data maupun setelah pengumpulan data selesai dilakukan. Proses analisis data yang digunakan dalam penelitian ini adalah model Miles dan Huberman (1992:20), yang terdiri atas langkah-langkah; 1) Reduksi data, 2) Penyajian Data, 3) Pengumpulan Data, dan 4) Penarikan kesimpulan dan verifikasi data.

\section{HASIL DAN PEMBAHASAN}

\section{Aspek Komunikasi}

Hasil penelitian terhadap aspek komunikasi dalam implementasi sistem informasi manajemen berbasis teknologi informasi di UNM berdasarkan hasil wawancara dengan informan penelitian dapat disimpulkan berada dalam kondisi tidak efektif. Kurangnya pemahaman informasi antar berbagai unit yang ada dalam lingkungan UNM yang mempengaruhi kinerja implementasi sistem informasi manajemen berbasis teknologi informasi membuat sistem informasi manajemen berbasis teknologi informasi tersebut belum mampu 
menghasilkan informasi terpadu yang diperlukan bagi terlaksananya kegiatan akademis di lingkungan UNM.

Program yang dilaksanakan ICT Center sebagai unit yang bertanggung jawab terhadap sistim informasi manajemen berbasis teknologi informasi di UNM dapat dikatakan belum berjalan sesuai pemahaman, hakekat dan tujuan pengelolaan sistem informasi manajemen berbasis teknologi informasi. ICT Center belum mampu memenuhi sebagian besar kebutuhan informasi umum semua unit dalam organisasi atau dalam subunit organisasional. Sistem Informasi belum mampu menyediakan informasi bagi pemakai dalam bentuk laporan dan output dari berbagai simulasi layanan teknologi informasi yang dijalankan.

Tidak adanya pemahaman informasi mengenai keterkaitan sistem informasi manajemen berbasis teknologi informasi dengan subsistim lainnya, seperti fakultas/jurusan/prodi, lembaga penelitian, lembaga pengabdian kepada masyarakat, perpustakaan serta UPT lainnya di lingkungan UNM ditandai dengan tidak adanya link system yang optimal (hanya sekedar tautan biasa), semua data masih dikerjakan dengan cara manual. Padahal sistem informasi manajemen adalah serangkaian subsistem informasi yang menyeluruh dan terkoordinasi dan secara rasional terpadu mampu mentransformasi data sehingga menjadi informasi lewat serangkaian cara guna meningkatkan produktivitas dan mutu yang telah ditetapkan.

Sampai saat ini sistem informasi manajemen berbasis teknologi informasi di lingkungan UNM baru menyentuh permukaannya saja, yaitu terbatas pada pengembangan dan pengimplementasian sistem informasi akademik (simpadu), sistem informasi jurnal (e-journal), sistem informasi penerimaan mahasiswa baru (dalam web unm.ac.id), dan baru-baru ini diterapkan (tahun 2015) adalah sistem informasi finansial (SIFa) UNM. Sedangkan, sistem informasi lainnya, seperti sistem informasi kepegawaian (staf), sistem informasi barang dan inventaris, sistem informasi perpustakaan, sistem informasi penelitian dan pengabdian kepada masyarakat, dan sistem informasi kemahasiswaan dan alumni belum dikembangkan dan baru pada tahap perencanaan.

Fenomena tersebut di atas, menunjukkan sebagian kecil persoalan yang muncul dalam implementasi teknologi informasi di UNM. Tidak adanya rencana pengembangan teknologi informasi (renstra, roadmap, atau sejenisnya) yang menjelaskan sasaran implementasi teknologi informasi dan keterkaitannya dengan sasaran UNM, tidak adanya sistem untuk identifikasi kebutuhan, assessment, dan evaluasi terhadap dukungan teknologi informasi bagi kegiatan-kegiatan dalam lingkungan UNM, serta ketidakjelasan prosedur pelaksanaan kegiatan yang didukung oleh fasilitas teknologi informasi, menunjukkan bahwa UNM hanya memandang sistem informasi berbasis teknologi informasi sebagai sesuatu yang "terpisah" dari proses-proses lain yang dijalankannya. Seharusnya teknologi informasi bisa menjadi enabler bagi berbagai usaha peningkatan kualitas, efektivitas, efisiensi, dan akuntabilitas di lingkungan kampus.

\section{Aspek Sumber daya}

\section{1) Sumber daya manusia}

Sumber daya manusia pengelola sistem informasi manajemen berbasis teknologi informasi di ICT Center UNM sebagian besar memiliki pengetahuan dan kemampuan mengenai sistem informasi manajemen berbasis teknologi informasi berdasarkan pengalaman dan pelatihan. Sebagian besar dari sumber daya manusia pengelola memiliki latar belakang pendidikan beragam dan tidak berhubungan dengan teknologi informasi. Mereka terdiri dari beberapa pengelola yang berstatus sebagai dosen, dibantu oleh beberapa pegawai non pns yang mengisi 
divisi yang ada, seperti divisi administrator, divisi networking, divisi sistem informasi, divisi hosting (website), divisi riset dan pengembangan, divisi workshop dan training, dan divisi elearning dan pengembangan bahan ajar.

Hal inilah yang ditekankan oleh Van Meter Van Horn (dalam Wibawa et al., 1994:19) bahwa "sumber daya manusia sangat penting karena sebagai sumber penggerak dan pelaksana kebijakan". Faktor mutu sumber daya manusia pengelola teknologi informasi merupakan salah satu faktor penentu. Sebaik atau selengkap apapun sarana dan prasana yang disediakan lembaga dalam membantu pekerjaan manajerial ataupun operasional, tidak akan berarti atau memiliki manfaat yang sedikit jika SDM yang melaksanakan, mengoperasikan, atau mengelola TIK tersebut berkualitas rendah. Untuk itu, efektivitas penggunaan TIK selain menyiapkan nilai dan norma yang tercakup dalam budaya, juga perlu mempersiapkan SDM yang berkualitas tinggi. Yaitu SDM yang well-educated, well tranined, memiliki etos kerja yang tinggi, motivasi yang tinggi.

Pengelola ICT Center
mengatasi persoalan-persoalan
muncul biasanya diselesaikan
reaktif decara
dan ad-hoc, sehingga
penyelesaiannya tidak tuntas dan selalu ada kemungkinan persoalan yang mirip akan muncul kembali pada masa yang akan datang. Jika hal ini dibiarkan terus berlangsung, UNM akan kehilangan momentum untuk mendapatkan dukungan dari teknologi informasi. Tidak adanya rencana pengembangan teknologi informasi, ketidakjelasan penanggung jawab implementasi teknologi informasi jika terjadi kerusakan (apakah menjadi tanggung jawab universitas atau fakultas), tidak adanya sistem untuk identifikasi kebutuhan terhadap dukungan teknologi informasi bagi kegiatan-kegiatan kampus (masih banyak area di fakultas dan gedung perkuliahan di gedung flamboyan yang tidak terkoneksi dengan jaringan internet), dan ketidakjelasan prosedur pelaksanaan kegiatan (dosen luar biasa merangkap operator prodi dengan sistem kerja dan pemberian insentif yang tidak jelas), termasuk prosedur penanganan kejadiankejadian, menunjukkan indikasi bahwa kemampuan manajerial dan kemampuan operasional ICT Center berada pada titik yang rendah.

\section{2) Sumber daya finansial}

Dari hasil penelitian, diketahui bahwa pengadaan berbagai sarana dan fasilitas teknologi informasi di UNM, baik perangkat keras maupun perangkat lunak seringkali dilakukan dalam kondisi operasional yang tidak ideal: dana yang terbatas, sistem anggaran yang kurang mendukung. Pimpinan universitas dan fakultas perlu melakukan evaluasi terhadap utilitas dan kemanfaatan yang ditimbulkan oleh sarana dan fasilitas teknologi informasi yang telah diinvestasikan. Jangan sampai manajemen sistem informasi berbasis teknologi informasi ini tidak dilandasi kerangka yang jelas, atau secara "instink" saja.

Dengan keterbatasan ini, pihak universitas harus melakukan penyesuaianpenyesuaian. Tim pengadaan perlu membuat daftar prioritas kebutuhan. Sebelum itu, tim sebaiknya juga mengevaluasi kembali spesifikasi kebutuhannya. Perlu ada penajaman untuk membedakan antara mana yang menjadi kebutuhan pokok dan yang menjadi kebutuhan sekunder, karena proses pengadaan sarana dan prasarana sistem informasi manajemen berbasis teknologi informasi (perangkat keras) harus mengikuti sistem pengadaan barang pada umumnya (sesuai ketentuan pemerintah yang berlaku), sehingga tidak semua kebutuhan teknologi informasi dapat diadakan dengan segera. Dalam konteks pemanfaatan teknologi informasi, perlu perencanaan yang baik sehingga tidak terjadi pembengkakan biaya. Jangan sampai teknologi informasi tersebut 
bahkan menjadi beban bagi institusi, bergeser dari fungsi aslinya sebagai pendukung. Institusi harus mengeluarkan biaya pemeliharaan untuk sarana dan fasilitas teknologi informasi, tetapi kemanfaatan yang dihasilkannya rendah. Untuk itulah melakukan perencanaan teknologi informasi perlu mulai di budayakan dalam kehidupan kampus. Kebiasaan membuat program tanpa didasari justifikasi yang kuat sebagai hasil perencanaan harus diubah menjadi praktek-praktek yang lebih baik, logis, dan sistematis.

Seharusnya, keberadaan sistem informasi berbasis teknologi informasi yang dikelola oleh ICT Center dapat memberikan nilai tambah secara nyata bagi unit-unit lainnya yang membutuhkan data dan informasi. Termasuk dalam kegiatan akademik, pihak universitas perlu mendorong pemanfaatan teknologi kontemporer seperti e-learning dalam proses-proses pembelajaran, sehingga besarnya investasi dana yang telah dikeluarkan untuk pengembangan dan pengimplementasian sistem informasi berbasis teknologi berbanding lurus dengam manfaat yang diperoleh oleh seluruh unit dalam lingkungan UNM, sehingga tidak menimbulkan resistensi terhadap keberadaan ICT Center dengan segala biaya yang telah dikeluarkan untuk membiayai operasional kegiatannya.

\section{b. Sikap pelaksana}

Hasil penelitian menunjukkan bahwa diperlukan identifikasi kebutuhan dan pemilihan aplikasi teknologi informasi yang sesuai dengan kebutuhan UNM sebagai penyelenggara pendidikan tinggi, disamping menghasilkan sarjana pendidikan, juga menghasilkan sarjana profesional non kependidikan, sehingga pihak eksternal UNM dapat mengakses sistem informasi tersebut dalam rangka mendapatkan informasi-informasi penting terkait kompetensi lulusan yang dapat diserap oleh mereka menjadi tenaga kerja siap pakai. Pemilihan aplikasi perlu mempertimbangkan keseimbangan antara unsur inovasi dan realitas yang ada. Inovasi berbicara tentang kemampuan mengidentifikasi cara-cara baru yang lebih efektif dan efisien melalui pemanfaatan teknologi informasi. Tujuannya adalah memaksimalkan nilai dan manfaat yang diperoleh dari penggunaan komputer dan aplikasi-aplikasinya. Inovasi pada akhirnya perlu dihadapkan pada kerangka arsitektur teknologi informasi, sumber daya, bahkan kultur/budaya yang ada. Bagaimanapun juga semua itu merepresentasikan realitas dan praktek yang dilakukan oleh pihakpihak di UNM. Mengubah dari kondisi yang ada saat ini sering kali memerlukan usaha yang ekstra keras.

Hal lain yang menjadi resistensi sikap pengelola adalah fasilitas untuk menunjang kegiatan online tersebut masih kurang, komitmen dari pimpinan, dosen dan mahasiswa belum searah sehingga sistem online ini kadang tidak digunakan secara maksimal. Teknologi informasi diadakan untuk memperbaiki/ menyempurnakan proses-proses akademik dan administratif, serta munculnya layanan-layanan baru yang inovatif. Tujuan dasar pemanfaatan teknologi informasi adalah perbaikan dan penyempurnaan dari apa yang ada saat ini. Manifestasinya bisa berupa tingkat kemudahan, kecepatan, produktivitas, akurasi, efisiensi, dan transparansi yang lebih tinggi. Apa yang dulu tidak bisa dikerjakan, sekarang hal ini menjadi mungkin karena bantuan teknologi informasi.

Penyediaan layanan KRS on-line misalnya, harus disertai dengan perubahan proses/tahapan KRS. Kewajiban menghadap dosen pembimbing akademik untuk meminta tanda tangan, otorisasi beban SKS yang akan diambil dapat dihilangkan, karena tugas ini diambil alih oleh komputer. Untuk keperluan yang lebih spesifik, perluasan akses informasi dapat dimanfaatkan pula untuk mendukung kegiatan pembelajaran yang lebih merata, efektif, dan berkualitas. Pembelajaran pada 
hakekatnya adalah proses akuisisi pengetahuan, dan hal ini dicapai melalui komunikasi informasi. Mahasiswa mengakses materi kuliah elektronis dari server universitas, dosen mencari informasi di Internet untuk bahan kuliahnya, atau mahasiswa berdiskusi dengan sesamanya lewat forum-forum online, semua itu adalah manifestasi komunikasi informasi yang bisa difasilitasi oleh sistem informasi manajemen berbasis teknologi informasi.

Dari fenomena tersebut di atas, maka keterjangkauan akses dan jumlah personalia pengelola sistem informasi manajemen berbasis teknologi informasi di UNM harus ditambah dan benar-benar ahli di bidang teknologi informasi. Untuk memperbaiki kesalahan/error yang sering terjadi selama ini membutuhkan waktu yang cukup lama jika sistem atau jaringannya bermasalah, dan petugas yang berkewajiban untuk memperbaikinya sedang dalam keadaan sibuk, sehingga harus menunggu dan menunda pekerjaan yang sedang dilakukan. Keterjangkauan akses diwujudkan dengan rancangan infrastruktur teknologi informasi yang baik. Komponen utamanya adalah jaringan komputer dan terminal sebagai titik akses.

\section{SIMPULAN}

Berdasarkan hasil penelitian mengenai implementasi sistem informasi manajemen berbasis teknologi informasi di lingkungan UNM, maka dapat disimpulkan sebagai berikut:

1. Implementasi sistem informasi manajemen berbasis teknologi informasi di UNM dilihat dari aspek komunikasi belum berjalan efektif. Hal ini dapat dilihat dari kurangnya tingkat pemahaman informasi dari pimpinan atas sampai kepada pelaksana yang memuat kejelasan isi, tujuan, arah, kelompok sasaran, dan pembagian tugas yang spesifik dari implementasi sistem informasi manajemen berbasis teknologi informasi di UNM.
2. Implementasi sistem informasi manajemen berbasis teknologi informasi di UNM dilihat dari aspek sumber daya (manusia dan finansial) kurang berjalan efektif. Hal ini dapat dilihat dari kuantitas sumber daya manusia pengelola profesional masih kurang, kualitas sumber daya manusia pengelola kurang inovatif dan kreatif dalam mengembangkan sistem aplikasi, dan dukungan dana yang ada terbatas hanya pada standar minimal layanan.

3. Implementasi sistem informasi manajemen berbasis teknologi informasi di UNM dilihat dari aspek sikap pelaksana menunjukkan resistensi dalam hal kurang optimalnya kinerja layanan dan jaringan sebagai akibat ketidakterjangkauan akses keseluruh unit-unit yang ada dalam lingkungan UNM.

\section{DAFTAR PUSTAKA}

Abidin, Said Zainal. 2004. Kebijakan Publik. Jakarta: Yayasan Pancur Siwah.

Bogdan dan Taylor. 1992. Pengantar Metode Penelitian Kualitatif: Suatu Pendekatan Fenomenologis terhadap Ilmu-ilmu Sosial. Surabaya: Penerbit Usaha.

Dunn, William N. 2003. Analisis Kebijakan Publik. Yogyakarta : Gadjah Mada University Press.

Dwidjowijoto, Riant Nugroho. 2003. Kebijakan Publik, Formulasi, Implementas, dan Evaluasi. Jakarta: Elex Media Komputindo

2006.

Kebijakan Publik Untuk Negara Negara Berkembang. Jakarta: Elek Media Komputindo.

Miles, B. Matthew dan A. Michael Huberman. 1992. Analisis Data Kualitatif. (Terjemahan oleh Tjetjep Rohendi Rohidi). Jakarta: UI-Press. 
Naihasy, S. 2006. Kebijakan Publik (Public Policy): Menggapai Masyarakat Madani. Yogyakarta: Mida Pustaka.

O'Brien, James. A. 2005. Pengantar Sistem Informasi Perseptif Bisnis dan Manajerial. Terjemahan. Jakarta: Salemba Empat.

Salusu, J. 2003. Pengambilan Keputusan Stratejik Untuk Organisasi Publik dan Organisasi Nonprofit. Jakarta: PT. Gramedia Widia Sarana Indonesia. Jakarta.

Setiawan, Guntur. 2004. Implementasi Dalam Birokrasi Pembangunan. Jakarta: Cipta Dunia.

Subarsono. 2005. Analisis Kebijakan Publik Konsep, Teori dan Aplikasi. Yogyakarta: Pustaka Pelajar.

Sugiyono. 2006. Metode Penelitian Pendidikan Administrasi. Bandung: Alfabeta.

Sunggono, Bambang. 1994. Hukum dan Kebijaksanaan Publik. Jakarta: Sinar Grafika.
Tangkilisan, Hesel Nogi. 2003. Implementasi Kebijakan Publik. Yogyakarta: Offset YPAPI.

Thompson, Ronald L, Haggings, Christoper A., dan Howell, Jane M. 1991. Personal Computing: Toward a Conceptual Model of Utilization. Mis Quarterly, pp.125143.

Undang-undang Republik Indonesia Nomor 11 Tahun 2008 tentang Informasi dan Transaksi Elektronik.

Wahab Solichin, Abdul. 2004. Evaluasi kebijakan Publik. Malang: Penerbit FIA UNIBRAW dan IKIP Malang.

Wibawa, Samodra. 1994. Evaluasi Kebijakan Publik. Jakarta: PT Raja Grafindo Persada.

Winarno, Budi. 2002. Teori dan Proses Kebijakan Publik. Yogyakarta: Media Pressindo.

Widodo, Joko. 2009. Analisis Kebijakan Publik. Malang: Bayumedia Publishing. 